\title{
Open Access Journal of Agricultural Research
}

\section{The Function of Molybdenum and Boron on the Plants}

\author{
Naqib SA and Jahan MS* \\ Department of Agricultural Science, Faculty of Bioresources and Food Industry, \\ University Sultan Zainal Abidin, Malaysia
}

*Corresponding author: Md Sarwar Jahan, Faculty of Bio resources and Food Industry,

Mini Review

Volume 2 Issue 3

Received Date: January 042017

Published Date: April 17, 2017 sarwarjahan@unisza.edu.my

\section{Abstract}

Plants favour to micronutrients to maintain physiological balance in plants to maintain growth and development of the plants. Molybdenum (Mo) and Boron (B) are essential micronutrients of the plants have a crucial role in growth and yield of the plants. Modern intensive agriculture gradually gains higher interest and importance of micronutrients to the researchers due to the diverse functional activities on plants. Documentation on the function of Molybdenum (Mo) and Boron (B) on the growth and production of the crops were not accounted considerably. This mini-review point several improvements made in the communication of Mo and B with other nutrients in growth and development of the rice plants.

Keywords: Micronutrients; Rice plant; Plant physiology; Yield growth

\section{Introduction}

Rice is staple food in Malaysia but also other parts of the world for all races and indigenous peoples. Different varieties of rice in the market including local white rice, brown rice, imported white rice, fragrant rice, Basmati rice, glutinous rice, parboiled rice and broken rice. Rice is planted as wet paddy in Peninsular Malaysia (503,184 ha) and at Sabah and Sarawak about 165,888 ha [1]. Although Malaysia is a primary consumer of rice but current production is not enough to meet the requirement to fulfil the demand of the country. Thus, with enormous complexity in the rice industry, it makes policy and planning for future prospect to increase rice production. In 2012, FAO had recorded 2.7 million tons of rice that fulfilled $70 \%$ of the demand in Malaysia [2]. However, climate changes affect the efficiency of the mineral transportation into the rice plant that uncertain the sustainable production of rice. To date, proper documentation on the effectiveness of Mo and B on rice production was not presented. Therefore, this mini- review was taken to file out the current information on Mo and $\mathrm{Zn}$ in regards to crop production.

Rice is the most growing plants in Malaysia and also another part of the world. It is a seasonal crop that has physical appearances like hollow, round, sessile leaf blades with collars and terminal panicles. Most of the rice consumed in Asia and West Indies that is region consists of Caribbean Sea. In rice plant development, we divided them into three stages which are germination to panicle (vegetative), panicle initiation to heading (reproductive) and grain filling and ripening or maturation (maturation) [3]. This plant is suitable to grow in high rainfall countries with low labor cost because it needs very laborious to care. It has many predators such as birds, mouse and also prone to diseases [4].

Rice is usually produced under flooding water condition. Land use policy and water management in Africa studied justifiably [5]. But there are several practices were taken to sustain rice production that is low 


\section{Open Access Journal of Agricultural Research}

water supply rice production [6-8] and increases the phytoavailability of nutrients under low water condition $[9,10]$, glutathione-induce physiological functions and production [11-16]. Therefore, the full understanding of the function of Mo and B in sustainable rice production and maintain growth and development of the rice plants to be justified properly.But to date, the effects of Mo and B on rice plants in gene profiling and antioxidant activities were not properly documented. Therefore, proper documentation of $\mathrm{Mo}$ and $\mathrm{B}$ on rice plants to be documented under different stress conditions which to be introduced by the climate change condition.

\section{Molybdenum}

Molybdenum is the one of essential micronutrients and availability of the Mo in soil depends on the several factors such as absorbing oxides concentration, soil $\mathrm{pH}$, existing of organic compounds that present in the soil compositions [17]. Molybdenum presents in varies complexes like molybdenite $\left(\mathrm{MoS}_{2}\right)$, wulfenite $\left(\mathrm{PbMoO}_{4}\right)$ and ferrimolybdenite $\left[\mathrm{Fe}_{2}\left(\mathrm{MoO}_{4}\right)\right]$. This solid mineral increases Mo in soil through weathering process that is related to the oxidation and reduction processes in soil. However, then, molybdenum is much more soluble in the alkaline soils and easy to access by plants in the form of $\mathrm{MoO}_{4-}$ [18]. In an acidic soil, availability of the molybdenum decreases as the adsorption of anion to soil oxides increase [19]. Molybdenum is needed by the plant in a small amount ranged from 12 to $32 \mathrm{~g} \mathrm{ha}^{-1}$ for physiological function [20] but the effect of Moon plants is as like as other essential nutrients. The critical deficiency and toxicity levels vary from 0.1 to $1 \mathrm{mg} \mathrm{kg}-1$ depend on the plant species and the plant parts that being analyzed [21].

\section{The Functions of Molybdenum on Morphological and Physiological Parameters of Plant}

Molybdenum application increased the fresh weight of Chinese cabbage but the excess application of molybdenum (1.5 $\mathrm{mg} \mathrm{l}^{-1} \mathrm{Mo}$ ) decreased the fresh weight [22]. Molybdenum fertilizer had an influence on growth, yield and qualities in winter wheat and Brassica napus [23]. Deficiency of molybdenum on a plant can diverge into developing of mottling lesions on the leaves and altered leaf morphology where lamellae became involuted or 'whiptail' [24]. Deep investigation of the ultrastructure of whiptail shows that chloroplasts near lesions became bulbous and enlarged with spherical protrusions bounded by chloroplast and tonoplast membrane [25]. On the other hand, the plant is in the toxicity level of molybdenum, leaf tends to have purple colour through an accumulation of anthocyanins but in legume shows yellow colour [26]. In a young plant, deficiency of Mo can effect on the mottling, leaf cupping, gray tinting and flaccid leaves that often found on seedlings that remained dwarfed until dying [27]. In wheat and oat plants, necrotic regions are observed on the leaf blade and seeds are poorly developed and shriveled in a plant in which deficient in molybdenum [28]. In maize, molybdenum deficiency shortens internodes, decreases leaf areas and causes the development of chlorotic leaves [29]. It can affect the reproductive part of the plant like emergence of tassels, small anther, poorly developed stamens, and pollen grain [30]. Pollen is released from the anthers shown to be shrivelled and have poor germination rates [29].

Molybdenum catalytically inactive in biological systems until bind to the co-factor. Molybdenum involves in several physiological processes in plants that are important for the plants to survive and reproduce. Mo functions on nitrogenase activity in root nodules and nitrite reductase in the vegetative tissue [31]. Mo presents together with nitrate enhanced enzyme activity which is a slow process and needs to have mRNAdependent synthesis of apoprotein, but enzyme activity will be faster if molybdenum is present [32]. Leguminous plants are very sensitive to molybdenum deficiency but excess can lead to decreasing of biomass, seed yield and deteriorates the quality of production [33]. Deficient of Mo decreases a total number of proteins in a plant [34].

Molybdenum plays a major role in the aldehyde oxidase for plant development and adaptation to environmental stresses. Total ascorbate concentrations in the Chinese cabbage increased with molybdenum application rates [22]. Molybdenum application promotes growth and yields of vegetables and also improves qualities such as ascorbic acid, soluble sugar and chlorophyll concentrations and induces the decrease of nitrate concentration [23]. Plants that are deficient from this molybdenum may exhibit poor growth and low contents of chlorophylls and ascorbic acid [21]. Molybdoenzymes are involved in phytohormone synthesis ABA and indole-3-acetic acid [35]. Furthermore, Mo involves in the oxidation of sulphite to sulphate through mediated with molybdoenzyme [31]. Sometimes Mo involves as a cofactor in the nitrogen fixation but absent of Mo causes stunted growth of the plants through affecting the photosynthetic activities [36]. Rice plants 


\section{Open Access Journal of Agricultural Research}

grown in the molybdenum deficiency soil, showed phenotypes develop error that hinder the plant growth. For examples, enzymes such as nitrate reductase and nitrogen-fixing enzymes nitrogenase that are abundantly present in legumes, xanthine dehydrogenase/oxidase that functions in catabolism of purine and ureide biosynthesis, aldehyde oxidase that present in ABA biosynthesis and sulphite oxidase that can convert sulphite to sulphate a vital step in catabolism of sulphur containing amino acid that important to plant metabolism [37]. Plants that exhibit with molybdenum deficiency tend to have poor growth and low contents of chlorophylls and ascorbic acid [21].

\section{The Functions of Molybdenum on Other Nutrients Availability}

Mo affects phytoavailability of other nutrients to plants or in soil. Mo has not position or negation relationship with zinc and copper availability but affect iron nutrient. Mo leads to Fe-chlorosis and yield diminution without correlation and manganese efficiency with correlation. Mo has significant effect on percentage of shoot nitrogen and potassium in rice. For phosphorus, with the increasing rates of molybdenum, the percentage of shoot phosphorus increases as well [38]. These results confirm that Mo might affect positively with some nutrients to be available to the plants. Chatterjee C, et al. (1985) [39] reported that molybdenum deterring phosphatase activity to decrease the total amount of phosphorus in mustard. However, higher level of Mo increases the effectiveness of phosphorus in plants [40]. Therefore, Mo application certainly reduced the requirement of phosphate for maximum growth of the plants. The activity of Mo varies upon varieties of rice plant. Mulder EG (1954) [41] reported that higher amount of manganese sulphate in soil enhanced Mo deficiency. This result indicates the negative interaction between manganese and Mo in soil.

\section{Boron}

Boron is a non-metal micronutrient that is required for normal growth and development of the plant. It is an immobile micronutrient functions on cell wall strength and development, fruit and seed development, transport of sugar, development of hormone, membrane function, ribonucleic acid (RNA) metabolism, cell division, respiration and indole-acetic acid (IAA) metabolism [42]. Moreover, it is essential for other plant physiological functions such as carbohydrate and protein metabolism, indole acetic acid metabolism, cell wall synthesis, and phenol metabolism [42]. Boron presents as a metal at wide ranges of $\mathrm{pH}$ of soil [43]. The concentration present is around 20 to $200 \mathrm{mg} \mathrm{B} \mathrm{kg-1}$ and available concentration varies differently depending on the soil types [44]. Usually, B is applied in semiarid tropical regions, calcareous and sandy soils [35].

In soil, boron is absorbed by roots in the form of un dissociated boric acid $\left[\mathrm{B}(\mathrm{OH})_{3}\right.$ or $\left.\mathrm{H}_{3} \mathrm{BO}_{3}\right]$ that has the capability to form complexes like diols and polyols inside the plant physiological processes [45]. Soil texture, $\mathrm{pH}$, temperatures and soil moisture affect the availability of boron in soil [46]. Boron is the only micronutrient that is absorbed not as an ion but is taken up as an uncharged molecule [21]. Boron absorption by plant roots is closely related to $\mathrm{pH}$ and concentration of boron in that soil and it is a non-metabolic process [47]. Mass flow is the primary mechanism of boron to enter into plant roots and distribution inside the plant by applying transpiration stream through the xylem [48]. Most of the boron deficiency occurs on coarse-textured soils with the low status of organic matter [49].

\section{Functions of Boron on Physiological and Morphological Parameters of Crops}

Boron affects reproductive growth of plants such as poor anther and pollen development, lower grain setting as well as stunted growth $[50,51]$. Boron increases tube growth in wheat plants [50]. Deficiency of boron impairs plant roots, meristimatic region [52]. To expand cell, plant cell walls need to be loosening thus give them some space to grow, and this was related to ascorbate and dehydroascorbate presence [53]. Moreover, ascorbate free radical (AFR)-mediated increase in elongation and meristematic regions in onion roots [54]. Boron is vital in the germination of pollen and growth of a pollen tube [55]. Boron increased protein concentration in a bean that actively works in the growing regions, which could be reduced by the lower rate of protein synthesis by boron deficiency [56]. Moreover, deficiency of boron increased the concentration of reducing sugar and non-reducing sugar but decreased the phosphorylase activity. On the other hand, in the sunflower seeds accumulated decreasing amount of non-reducing sugar and starch concentration [57].

Boron affects lipid biosynthesis, lipid oxidation and proton pumping [58]. Sunflower seedlings were treated with $10 \mu \mathrm{M}$ boron and observed that lipid has decreased in neutral acid and increase in linolenic acid concentration compared to control group. Since lipid also 


\section{Open Access Journal of Agricultural Research}

a compartment of lipid in the membrane, thus the presence of boron can have consequences on the bridging of lipids via hydroxyl groups and affect their functions and structure. Other study showed that effect of boron on the membrane function related to the proton pumping or changes in redox system in plasmalemma. An activity of plasmalemma NADH oxidase was linked by boron stimulation [59]. NADH oxidase functional as ascorbate free radical (AFR) reductase in a plant [60]. Thus, boron involved in the ascorbate metabolism and NADH biological role. Since NADH also participating in the NADH activity so it was also involved in the cell wall extension and transport in the membrane factor. Boron functions in protoplast membrane fraction to the whole protoplast [61] which shows that boron has an impact towards the membrane compartments.

Boron might serve as important roles as cell wall structure building up and accomplish in the biosynthesis of the lignin and cell-wall cross-linking [62]. Plants that were grown in the boron nutrient tend to be more easily than a plant that was not grown in boron nutrient; more brittle [62]. The primary that comes from boron is disruption of the normal functioning of the apical meristems with changes in membrane structure, cell wall synthesis, metabolism of auxin, carbohydrate, ascorbate and RNA and lignification, phenol accumulation and sucrose transport being secondary effects [61].

\section{Boron Functions on Other Nutrient's Availability}

Boron has many physiological and biochemical processes that can affect to other nutrients thus it is very complex to make the conclusion about that. Boron plays a vital role in the nutrient transport by plant membranes [63]. Boron influences plant nutrients [64,65]. Excessive intake of boron affects metabolic processes and reduces other nutrients availability to the plants [66], an antagonistic effect on the uptake of nutrients in the wheat plant [67], a synergistic effect on the absorption of nutrients by tomato plants [65]. N-Rase activity markedly increased in rape plants in the presence of boron. In contrast, Pollard et al. (1977) [68] reported that boron deficiency reduced ATPase activity that affects the absorption of phosphate in corn and broad beans. Chatterjee et al. (2001) [69] stated similar relationship between boron and phosphorus in plants. Calcium and boron regulate auxin transport process in cell wall metabolism [70], the activity of starch, phosphorylase, ribonuclease and polyphenol oxidase increased [39].
An absence of $\mathrm{B}$, the nutrients such as $\mathrm{N}, \mathrm{K}, \mathrm{Ca}, \mathrm{Mg}, \mathrm{Na}$, $\mathrm{Cu}$ and $\mathrm{Mn}$ in tobacco leaves increased, and $\mathrm{P}, \mathrm{Fe}$ and $\mathrm{Al}$ decreased as compared to plants fed with a B [71]. P, K and $\mathrm{Mg}$ were higher and $\mathrm{Ca}$ was lower in severely $\mathrm{B}$ deficient alfalfa plant than healthy ones, perhaps due to the dilution effect which occurred in healthy plants [72]. $\mathrm{Cu}$ and $\mathrm{K}$ contents showed a highly significant positive correlation, while $\mathrm{Ca}$ and $\mathrm{Mg}$ contents showed a negative correlation with B contents of 98 kinds of grass at the flowering stage [73]. Touchton and Boswell, (1975) [74] observed that $\mathrm{P}, \mathrm{K}, \mathrm{Ca}, \mathrm{Mg}, \mathrm{Na}, \mathrm{Zn}, \mathrm{Cu}, \mathrm{Fe}, \mathrm{Mn}, \mathrm{Mo}$ and $\mathrm{Al}$ concentrations varied slightly with location, but were not affected by the method or rate of $\mathrm{B}$ application. In addition, increasing B supply in soil resulted in the decrease of leaf $\mathrm{N}$ and $\mathrm{P}$ in tomato, suggesting $\mathrm{B}$ antagonism [75]. Yadav and Machanda (1979) [76] noted that with an increase in the B content of soil, tissue Ca and $\mathrm{Mg}$ concentration in wheat and gram crops significantly decreased, whereas N, P and K contents were significantly increased. Downton and Hawker (1980) [77] reported that added $\mathrm{B}$ in nutrient solution, the concentration of $\mathrm{N}$, $\mathrm{P}, \mathrm{Ca}, \mathrm{Mg}$ and $\mathrm{B}$ were decreased, $\mathrm{K}$ increased, while $\mathrm{Na}$ remained unaffected in lamina, stem and roots of cabernet sauvignon vine plants. Gomez-Rodriguez, et al. (1981) [78] found a significant inverse correlation between $\mathrm{B}$ and $\mathrm{Mn}$ concentration in the leaves of sunflower, while $\mathrm{Cu}, \mathrm{Fe}$ and $\mathrm{Zn}$ concentrations remained unchanged by B levels in nutrient solution. Likewise, Dave and Kannan (1981) [56] observed that a reduction of Fe and $\mathrm{Mn}$ adsorption but an increase in $\mathrm{Zn}$ uptake was found in a B deficient medium. The transport of $\mathrm{Fe}, \mathrm{Mn}$ and $\mathrm{Zn}$ was increased in the trifoliate leaves, while that in shoots was reduced. The detrimental effect of B on the uptake of $\mathrm{Ca}$ and $\mathrm{Mg}$ was reported by Singh V, Singh SP (1983) [79], they found B levels significantly induced N, P, $\mathrm{K}, \mathrm{Na}$ and $\mathrm{B}$ but reduced $\mathrm{Ca}$ and $\mathrm{Mg}$ concentration in lentil plants. Moreover, Singh V, Singh SP (1984) [80] reported that B increase N, P, K, Na and B contents, but decreased Ca and Mg contents in barley crop. Francois (1984) [81] reported that increasing soil solution with B concentration, $\mathrm{P}, \mathrm{K}$ and $\mathrm{Mg}$ tended to increase in tomato leaf, while Ca and Na showed an inconsistent trend.

The above discussion confirmed that it is still needed to find more information on the functional effects of Mo and B field crops to sustain the production. The discussion gives idea to the scientist on the points to be highlighted in their further research. 


\section{Open Access Journal of Agricultural Research}

\section{References}

1. Nurul NR, Nasir MS, Zainalabidin M, Alias R (2012) The Impact of Fertilizer Subsidy on Malaysia Paddy/Rice Industry Using a System Dynamics Approach. International Journal of Social Science and Humanity 2(3): 213-219.

2. FAO (2012) Rice market monitor. FAO newsletter 17: $1-24$.

3. Jun-Ichi I, Nonomura KI, Ikeda Yamaki S, Inukai Y, Yamagishi H, et al. (2005) Rice Plant Development: from zygote to spikelet. Plant Cell Physiology 46(1): 23-47.

4. Slavko P, Patrick HB, Joseph HC, Agnes MSN, Christos D, et al. (2001) Foliar Boron Application Improves Flower Fertility and Fruit Set of Olive. Hortscience 36(4): 714-716.

5. Valipour M, Ahmadi MZ, Raeini-Sarjaz M, Sefidkouhi MAG, Shahnazari A, et al. (2015) Agricultural water management in the world during past half century. Archives of Agronomy and Soil Science 61(5): 657678.

6. Sarwar MJ, Khanif YM (2005a) Techniques of water saving in rice production in Malaysia. Asian J Plant Sci 4: 83-84.

7. Khairi M, Nozulaidi M, Jahan MS (2015) Effects of Different Water Levels on Physiology. Australian Journal of Basic and Applied Sciences 9(2): 339-345.

8. Jahan MS, Khanif YM, Sinniah UR (2013a) Effects of low water input on rice yield: $\mathrm{Fe}$ and $\mathrm{Mn}$ bioavailability in soil. Pertanika J Trop Agric Sci 36(1): 27-34.

9. Sarwar MJ, Khanif YM, Syed Omar SR, Sinniah UR (2004) The effect of different water regimes on yield and bioavailability of Phosphorus in rice production in Malaysia. Malaysian J Soil Sci 8: 53-62.

10. Jahan MS (2016) Rice Production under Different Water Inputs. LAP LAMBERT Academic Publishing.

11. Inani $N$, Nozulaidi $M$, Khairi $M$, Abdulkadir $A B$, Jahan MS (2015) Glutathione functions on physiological characters of corn plants to enhance Mn-induced corn production. Pertanika J Trop Agric Sci 38(4): 509518.
12. Jahan MS, Nozulaidi M, Khairi M, Mat N (2016) Lightharvesting complexes in photosystem II regulate glutathione-induced sensitivity of Arabidopsis guard cells to abscisic acid. J Plant Physiol 195: 1-8.

13. Jahan MS, Ogawa K, Nakamura Y, Shimoishi Y, Mori IC, et al. (2008) Deficient glutathione in guard cells facilitates abscisic acid-induced stomatal closure but does not affect light-induced stomatal opening. Biosci Biotechnol Biochem. 72(10): 2795-2798.

14. Jahan MS, Nordin MNB, CheLah MKB, Khanif YM (2013b) Effects of water stress on rice production:bioavailability of potassium in soil. J Stress Physiol Biochem 9: 97-107.

15. Syuhada N, Jahan MJ (2016) Glutathione functions on physiological characters to increase copper-induced corn production. Russ Agril Sci 42(1): 5-10.

16. Munirah N, Khairi M, Nozulaidi M, Jahan MS (2015a) The Effects of Zinc Application on Physiology and Production of Corn Plants. Aus J Basic Appl Sci 9(2): 362-367.

17. Brent NK, Kate LG, Joanne NB, Thomas P, Stephen DT (2005) The Role of Molybdenum in Agricultural Plant Production. Ann Bot 96(5): 745-754.

18. Fageria NK (2013) Mineral Nutrition of Rice. Florida: CRC Press.

19. Reddy KJ, Munn LC, Wang L (1997) Chemistry and mineralogy of molybdenum in soils. Cambridge: Cambridge University Press.

20. Singh MV (2008) Micronutrient deficiencies in crops and soils in India. Micronutrient Deficiencies in Global Crop Production 93-125.

21. Marschner H (1995) Functions of Mineral Nutrients. Micronutrients. In: Mineral Nutrition of Higher Plants (pp. 313-404). London: Academic Press.

22. Tan QL, Nie ZJ, Hu CX, Sun XC, Liu HE (2007) Effects of molybdenum on ascorbate-glutathione cycle metabolism in Chinese cabbage (Brassica campestris L. ssp. pekinensis). Plant Soil 295(1): 13-21.

23. Chen G, Nian FZ, Wang YH, Xu FS (2004) Effect of B, Mo on fatty acid component of Brassica napus. Chinese J Oil Crop Science 26(2): 69-71. 


\section{Open Access Journal of Agricultural Research}

24. Arnon DI, Stout PR (1939) Molybdenum as an essential element for higherplants. Plant Physiology 14(3): 599-602.

25. Fido RJ, Gundry CS, Hewitt EJ, Notton BA (1977) Ultrastructural features of molybdenum deficiency and whiptail of cauliflower leaves: Effects of nitrogen source and tungsten substitution for molybdenum. Australian Journal of Plant Physiology 4(4): 675-689.

26. Bergmann W (1992) Nutritional disorders of plants: Development Visual and analytical diagnosis. Stuttgart and New York: Gustav Fischer Verlag.

27. Imperial J, Hadi M, Amy NK (1998) Molybdate binding by ModA, the periplasmic component of the Escherichia coli mod molybdate transport system. Biochimica et Biophysica Acta 1370(2): 337346.

28. Anderson AJ (1956) Molybdenum deficiencies in legumes in Australia. Soil Science 81(3): 173-192.

29. Agarwala SC, Sharma CP, Farooq S, Chatterjee C (1978) Effect of molybdenum deficiency on the growth and metabolism of corn plants raised in sand culture. Canadian Journal of Botany 56(16): 19051909.

30. Agarwala SC, Chatterjee C, Sharma CP, Nautiyal N (1979) Pollen development in maize plants subjected to molybdenum deficiency. Canadian Journal of Botany 57(18): 1946-1950.

31. Srivastava P (1997) Biochemical significance of molybdenum in crop plants. New York: Cambridge University Press.

32. Hewitt EJ (1983) A perspective of mineral nutrition: essential and functional metals in plants. Metals and Micronutrients: Uptake and Utilization by Plants 18: 277-326.

33. Kevresan S, Petrovic N, Popovic M, Kandrac J (2001) Nitrogen and proteinmetabolism in young pea plants as affected by different concentrations of nickel, cadmium leda and molybdenum. J Plant Nutrition 24(10): 1633-1644.

34. Notton B (1983) Micronutrients and nitrate reductase. In: Robb DA, Pierpoint WS (eds.) Metals and Micronutrients: Uptake and Utilization by Plants (pp. 219-240). New York: Academic Press Inc.

Naqib SA and Jahan MS. The Function of Molybdenum and Boron on the Plants. J Agri Res 2017, 2(3): 000136.
35. Gupta UC (1997) Soil and plant factors affecting molybdenum uptake by plants. In: Gupta UC, ed. Molybdenum in agriculture. Cambridge: Cambridge University Press.

36. Tisdale SL (1985) Soil Fertility and Fertilizers. New York: Macmillan.

37. Mendel RR, Haensch R (2002) Molybdoenzymes and molybdenum cofactor in plants. Journal of Experimental Botany 53(375): 1689-1698.

38. Basak A, Mandal LN, Haldar M (1982) Interaction of phosphorus and molybdenum in relation to uptake and utilization of molybdenum, phosphorus,zinc,copper and manganese by rice. Plant Soil 68(2): 261-269.

39. Chatterjee C, Nautiyal N, Agarwala SC (1985) Metabolic changes in mustard plants associated with molybdenum deficiency. New Phytologist 100(4): 511-518.

40. Liu H, Chengxiao H, Xiaoming H, Zhaojun N, Xuecheng $S$, et al. (2010) Interaction of molybdenum and phosphorus supply on uptake and translocation of phosphorus and molybdenum by brassica napus J. Plant Nutr 33(12): 1751-1760.

41. Mulder EG (1954) Molybdenum in relation to growth of higher plants and micro- organisms. Plant Soil 5(4): 368-415.

42. Goldbach HE, Yu Q, Wingender R, Schulz M, Wimmer $M$, et al. (2001) Rapid response reactions of roots to boron deprivation. J Plant Nut Soil Sci 164: 173-181.

43. Epstein E, Arnold JB (2005) Mineral Nutrition of Plants: Principles and Perspectives. Sunderland and Massachusetts: Sinauer Associates Inc.

44. Mengel K, Kirkby EA (1987) Principles of plant nutrition. Switzerland: International Potash Institute.

45. Mengel K, Kirkby EA (1982) Principles of plant nutrition. Switzerland: International Potash Institute.

46. Wear JI, Patterson RM (1962) Effect of soil pH and texture on the availability of water soluble B in the soil. Soil Sci Soc Am Proc 26(4): 344-345.

47. Brown PH, Hening H (1998) Boron mobility and consequent management. In: Better Crops., 82: 28-31. 


\section{Open Access Journal of Agricultural Research}

48. Raven JA (1980) Short-and long-distance transport of boric acid in plants. New Phytol 84(2): 231-249.

49. Gupta UC, Monika AW, Sabine G (2007) Boron. In Handbook of Plant Nutrition (pp. 242-243). Canada: Taylor \& Francis Group.

50. Dalton DA, Russell SA, Hanus FJ, Pascoe GA, Evans HJ (1986) Enzymatic reactions of ascorbate and glutathione that prevent peroxide damage in soybean root nodules. Proc Nat Acad Sci USA 83(11): 38113815 .

51. Rashid A, Rafique E, Bughio N (1994) Diagnosing boron deficiency in rapeseed and mustard by plant analysis and soil testing. Comm Soil Sci Plant Ana 25(17-18): 2883-2897.

52. Gauch HG, Dugger WM (1954) The physiological action of boron in higher plants: a review and interpretation. USA: College Park, Md. University of Maryland, Agricultural Experiment Station.

53. Lin L, Joseph EV (1991) Expression of ascorbic acid oxidase in zucchini Squash (Cucurbita pepo L). Plant Physiol 96(1): 159-165.

54. Hidalgo A, Garcia-Herdugo G, Gonzalez-Reyes JA, Morre DJ, Navas P (1991) Ascorbate free radical stimulates onion root growth by increasing cell elongation. Bot Gaz 152(3): 282-288.

55. Jackson JF (1991) Borate control of energy-driven protein secretion from pollen and interaction of borate with auxin or herbicide-a possible role for boron in membrane events. Curr Top Plant Biochem Physiol 10: 221-229.

56. Dave IC, Kannan S (1981) Influence of Boron Deficiency on Micronutrients Absorption by Phaseolus vulgaris. Acta Physiologiae Plantarum 3: 27-32.

57. Hirsch AM, Helen MM (1983) Effects Of Boron Deficiency On Mitosis And Incorporation Of Tritiated Thymidine Into Nuclei Of Sunflower Root Tips. American Journal Of Botany 70(2): 165-172.

58. Donaire JP, Belver A (1985) Effect of boron on metabolic changes in cotyledons grown under dark and light conditions. J Plant Physiol 120(5): 389-399.

Naqib SA and Jahan MS. The Function of Molybdenum and Boron on the Plants. J Agri Res 2017, 2(3): 000136.
59. Barr R, Bottger M, Crane FL (1991) Boron stimulates NADH oxidase activity ofcultured. Curr Top Plant Biochem Physiol 10: 290.

60. Morre DJ, Brightman AO, Wu LY, Barr R, Leak B, et al. (1988) Role of plasma membrane redox activities in elongation growth in plants. Physiol Plant 73(1): 187193.

61. Parr AJ, Loughman BC (1983) Boron and membrane function in plants. In: Metals and Micronutrients: Uptake and Utilization by Plants (pp. 87-107) New York: (Eds.) Da Robb and WS Pierpoint Academic Press.

62. Loomis WD, Durst RW (1992) Chemistry and biology of boron. BioFactors 3(4): 229-239.

63. Tanada T (1983) Localization of boron in membranes. Plant Nutrition 6(9): 743-749.

64. Alvarez-Tinaut MC, Leal A, Agui I, Recalde-Martinez L (1979) Physiological effects of B-Mn interaction in tomato plants. II The uptake translocation of macro elements. Analysis of Soil Science and Agrobiology 38: 991-1012.

65. Carpena-Artes O, Carpena-Ruiz RO (1987) Effects of boron in tomato plant. Leaf Evaluations. Agrochimica 31: 391-400.

66. Corey RB, Schulte EE (1973) Factors affecting the availability of nutrients to plants. In: Soil testing and Plant Analysis (pp. 23-34). Wisconsin: Soil Sci Soc Am Inc.

67. Singh JP, Dahiya DJ, Narwal RP (1990) Boron uptake and toxicity in wheat in relation to zinc supply. Fertil Res 24(2): 105-110.

68. Pollard AS, Parr AJ, Loughman BC (1977) Boron in relation to membrane function in higher plants. J Exp Bot 28(4): 831-841.

69. Chatterjee C, Nautiyal N (2001) Molybdenum stress affects viability and vigour of wheat seeds. Journal of Plant Nutrition 24(9): 1377-1386.

70. Dela-Fuente RK, Tang PM, Guzman DCC (1986) Plant GrowthSubstances. Proceedings of the 12th international conference : Plant growth substances. Berlin: Marcel Deckker Inc. 


\section{Open Access Journal of Agricultural Research}

71. Steinburg RA, Specht AW, Roller EM (1955) Effects of micronutrient deficiency on mineral composition, Nitrogen fraction, Ascorbic acid and Burn of tobacco grown to flowering in water culture. Plant Physio 30(2): 123-129.

72. Baker AS, Cook RL (1959) Green house studies on alfalfa with soil type, soilreaction and borax fertilization as variables. Agron 51(1): 1-4.

73. Tolgyesi G, Kozma A (1974) Investigation on factors affecting boron uptake by grasses. Agrokemia-esTalajatan 23: 83-98.

74. Touchton JT, Boswell FC (1975) Effects of boron application on soybean yield, chemical composition, and related characteristics. Agronomy Journal 67(3): 417-420.

75. Aduayi EA (1978) Role of boron on growth components and elemental composition of plum tomato. Commun Soil Sci Plant Anal 9(1): 1-11.

76. Yadav OP, Manchanda HR (1979) Boron tolerance studies in gram and wheat grown on a sierozem sandy soil. J Indian Soc Soil Sci 27(2): 174-180.
77. Downton WJS, Hawker JS (1980) Interaction of boron and chloride ongrowth and mineral composition of cabernet sauvignon vines. Am J Enol Vitic 31: 277282.

78. Gomez-Rodriguez MV, Gomez-Ortega M, AlvarezTinaut MC (1981) Boron, copper, iron, manganese and zinc contents in leaves of flowering sunflower plants (Helianthus annuus L.) grown with different boron supplies. Plant Soil 62(3): 461-464.

79. Singh V, Singh SP (1983) Effect of applied boron on the chemical composition of lentil plants. J Indian Soc Soil Sci 31(1): 169-170.

80. Singh V, Singh SP (1984) Effect of applied boron on nutrients and uptake by barley crop. Curr Agric 8(12): $86-90$.

81. Francois LE (1986) Effect of excess boron on broccoli, cauliflower and radish. J Am Soc Hortic Sci 111: 494498. 